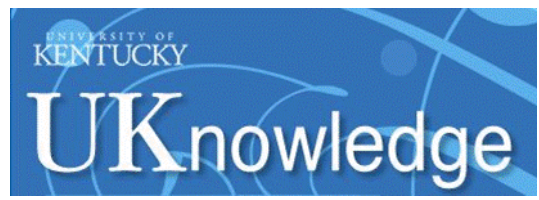

University of Kentucky

UKnowledge

Biosystems and Agricultural Engineering Faculty Publications

\title{
Designing Contour Weep Berms to Reduce Agricultural Nonpoint Source Pollution
}

\author{
Richard C. Warner \\ University of Kentucky, richard.warner@uky.edu \\ Carmen T. Agouridis \\ University of Kentucky, carmen.agouridis@uky.edu \\ Ross L. Guffey \\ University of Kentucky, rossguffey@gmail.com
}

Follow this and additional works at: https://uknowledge.uky.edu/bae_facpub

Part of the Bioresource and Agricultural Engineering Commons

Right click to open a feedback form in a new tab to let us know how this document benefits you.

\section{Repository Citation}

Warner, Richard C.; Agouridis, Carmen T.; and Guffey, Ross L., "Designing Contour Weep Berms to Reduce Agricultural Nonpoint Source Pollution" (2013). Biosystems and Agricultural Engineering Faculty Publications. 3.

https://uknowledge.uky.edu/bae_facpub/3

This Article is brought to you for free and open access by the Biosystems and Agricultural Engineering at UKnowledge. It has been accepted for inclusion in Biosystems and Agricultural Engineering Faculty Publications by an authorized administrator of UKnowledge. For more information, please contact UKnowledge@lsv.uky.edu. 
Designing Contour Weep Berms to Reduce Agricultural Nonpoint Source Pollution

Digital Object Identifier (DOI)

http://dx.doi.org/10.13031/aea.29.10044

Notes/Citation Information

Published in Applied Engineering in Agriculture, v. 29, no. 4, p. 521-528.

Copyright 2013 American Society of Agricultural and Biological Engineers

The copyright holder has granted permission for posting the article here.

This article is available at UKnowledge: https://uknowledge.uky.edu/bae_facpub/3 


\title{
DESIGNING CONTOUR WeEP BERMS TO REDUCE AgriCUltural NONPOINT SOURCE POLLUTION
}

\author{
R. C. Warner, C. T. Agouridis, R. L. Guffey
}

\begin{abstract}
Nonpoint source pollution (NPS) of surface waters is a significant issue in agricultural lands, and best management practices (BMPs) are often used to reduce these impacts. Since the effectiveness of a BMP depends on a large number of widely varying factors, it is important to continue to develop BMPs in order to provide designers with more tools to use to maximize NPS removal. The contour weep berm is a new structural BMP constructed out of earth and subsequently vegetated. It is a linear BMP that is used in combination with a down-gradient vegetated filter strip or forested riparian buffer. Preliminary field evaluations of the contour weep berm indicate it is effective at reducing runoff volumes and peaks, promoting infiltration, and reducing sediment concentrations in runoff. Procedures for designing a contour weep berm are presented along with a design example. Linear BMPs, such as the contour weep berm, can provide producers with another means of effectively controlling NPS.
\end{abstract}

Keywords. Best management practices, Environmental protection, Infiltration, Runoff, Structures.

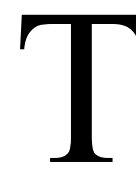
The 2010 National Water Quality Inventory notes that of the assessed water bodies in the United States, over $50 \%$ of the rivers and streams, nearly $70 \%$ of the lakes, reservoirs, and ponds, and over $80 \%$ of wetlands are impaired. Agricultural nonpoint source (NPS) pollution has been identified as the leading cause of this impairment for rivers and streams, the third largest for lakes, reservoirs, and ponds, and fourth largest for wetlands largely due to high levels of pathogens, sediments, and nutrients in agricultural runoff (USEPA, 2012). Waters contaminated by pathogens can result in illness for humans and livestock, contamination of irrigated produce, and economic losses for the producer (Rosen, 2000; Edge et al., 2012). High levels of sediment negatively impact aquatic life both directly through reductions in survival, growth, and reproduction (e.g., abrading gills, suffocating eggs and larvae, binding with chemical pollutants) and indirectly through habitat alterations that reduce resource access and/or quality (e.g., embedding riffles, filling pools, reducing visibility) (Vuori, 1995; Wood and Armitage, 1997; FISRWG, 1998; Sutherland and Meyer, 2007). Nutrient loadings from agricultural NPS promote eutrophication which in turn reduces or even depletes the water of dissolved oxygen. In the Midwestern and southern United States, nutrients in

Submitted for review in November 2012 as manuscript number SW 10044; approved for publication by the Soil \& Water Division of ASABE in April 2013.

The authors are Richard C. Warner, Extension Professor, Carmen T. Agouridis, ASABE Member, Assistant Professor, Ross L. Guffey, Graduate Student, Department of Biosystems and Agricultural Engineering, University of Kentucky, Lexington, Kentucky. Corresponding author: Carmen T. Agouridis, 128 C.E. Barnhart Building, Lexington, KY 40546-0276; phone: 859-257-3000 ext. 207; email: carmen.agouridis@uky.edu. runoff have significantly contributed to the formation of the hypoxic zone in the Gulf of Mexico (Rabalais et al., 2007; Diaz and Rosenberg; 2008).

Best management practices (BMPs) are often used to help reduce the impacts of NPS pollution on receiving waters. Ideally, these practices should be effective at reducing NPS and economical in terms of design and construction costs. Agricultural BMPs are divided into three categories: cultural control BMPs, structural control BMPs, and management control BMPs (Logan, 1990; Agouridis et al., 2005). Cultural control BMPs are designed to minimize the input of pollutants to waterways such as through rotational grazing or cropping and tillage practices (McFarland et al., 1999). As noted by Logan (1990), cultural control BMPs are designed to reduce soil erosion but in doing so may not reduce runoff or promote infiltration. Structural control BMPs are designed to modify the transport of NPS to water bodies largely by decreasing runoff volumes and rates as well as increasing infiltration (Logan, 1990; Agouridis et al., 2005; Warner et al., 2012). Examples of structural control BMPs include riparian buffers, vegetated filter strips, wetlands, and sediment basins). Management control BMPs focus on the producer's actions. Examples of such BMPs include fertilizer and pesticide application rates and integrated pest management (Logan, 1990).

Reducing NPS pollution is a challenging task. The effectiveness of a BMP depends on a number of factors such as the constituents of interest, slope, and sizing constraints. Generally, longer vegetated filter strips (VFS), for example, are more effective at trapping NPS than shorter ones (Dillaha et al., 1988; Dillaha et al., 1989; Magette et al., 1989; Madison et al., 1992; Castelle et al., 1994). Likewise, VFS tend to do well at trapping sediments (Daniels and Gilliam, 1996; Deletic and Fletcher, 2006; 
Gumiere et al., 2011; Yu et al., 2012) and sediment-bound constituents if flows are not concentrated (Dosskey et al., 2002; Baker et al., 2006) but are less effective at dissolved constituents (Dillaha et al., 1988; Roberts et al., 2012). Baker et al. (2006) noted that the ability of VFS to remove dissolved pollutants was largely related to the infiltration rates of the VFS itself. The authors stated that "infiltration is the most important process for reducing movement of [dissolved] pollutants" such as nitrate-nitrogen. The contour weep berm is used in conjunction with a VFS or forested riparian buffers in an effort to further enhance NPS removal by promoting infiltration and sedimentation.

A contour weep berm is a structural BMP constructed out of earth, and subsequently vegetated, and is used in combination with a down-gradient VFS or forested riparian buffer. Contour weep berms are constructed down-gradient of NPS generating activities such as land clearing, composting facilities, manure storage, manure application, and waste lagoons. The purpose of a contour weep berm is to control runoff by reducing peak flows thereby promoting sedimentation and infiltration and thus improving water quality. The Water Environment Federation (WEF) and the American Society of Civil Engineers (ASCE) (2012) note that most constituents are removed from infiltrating stormwater within the top 40 to $90 \mathrm{~cm}$ of soil. The contour weep berm is designed to completely capture and infiltrate frequently occurring small storm events. For larger, less frequent storm events, excess runoff slowly and passively exits via four pathways: infiltration, seepage through the earthen berm, multiple outlets (e.g., pipes) at a predefined level(s), and/or over the crest of the berm, which mimics a broad-crested weir (fig. 1). Runoff that exits the contour weep berm is directed across a VFS or forested riparian buffer for secondary passive treatment.

Contour weep berms are constructed along the contour and perpendicular to the direction of runoff. The ends of the contour weep berm, however, are perpendicular to the contour in order to provide runoff storage. The planform view of a contour weep berm resembles that of a horseshoe (fig. 2). For long contour weep berms, regularlyspaced earthen dikes are sometimes installed to separate the stored runoff into cells. The advantage of these cells is that if the contour weep berm is breached, only a portion of the stored runoff is released as opposed to the entire volume. As contour weep berms are linear control structures, less land is required for construction as compared to sediment ponds, which are a common-type of sediment-control BMP. Typically, contour weep berms are constructed along the perimeter of an agricultural activity such as a composting operation.

As the contour weep berm is a relatively new structural BMP, it has undergone limited field testing. Warner and Collins-Camargo (2001) used a contour weep berm and a forested riparian buffer to control sediment-laden runoff

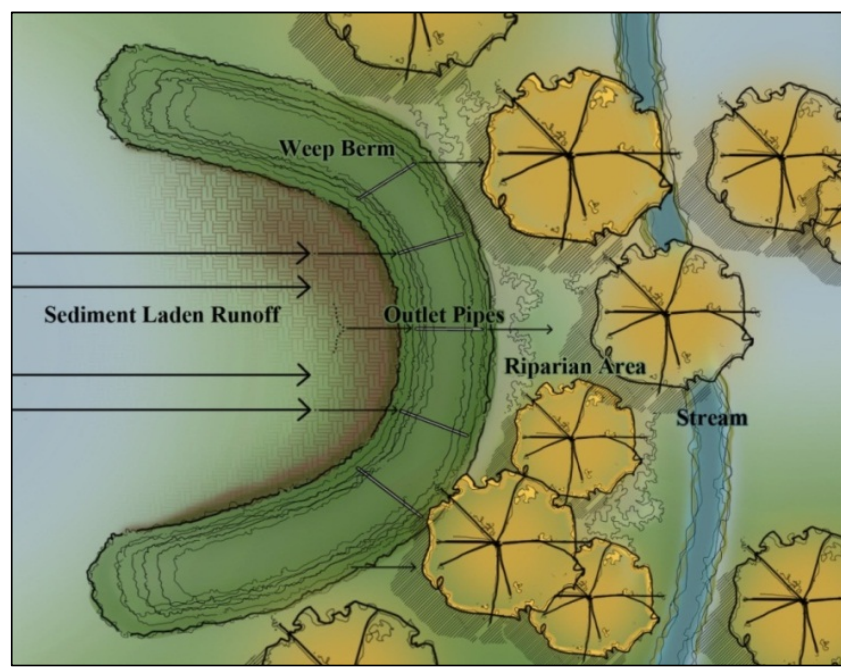

Figure 2. Planform view of a contour weep berm and down-gradient riparian buffer. The designer can use a vegetated buffer strip instead of a forested riparian buffer. Source: Warner et al. (2012).

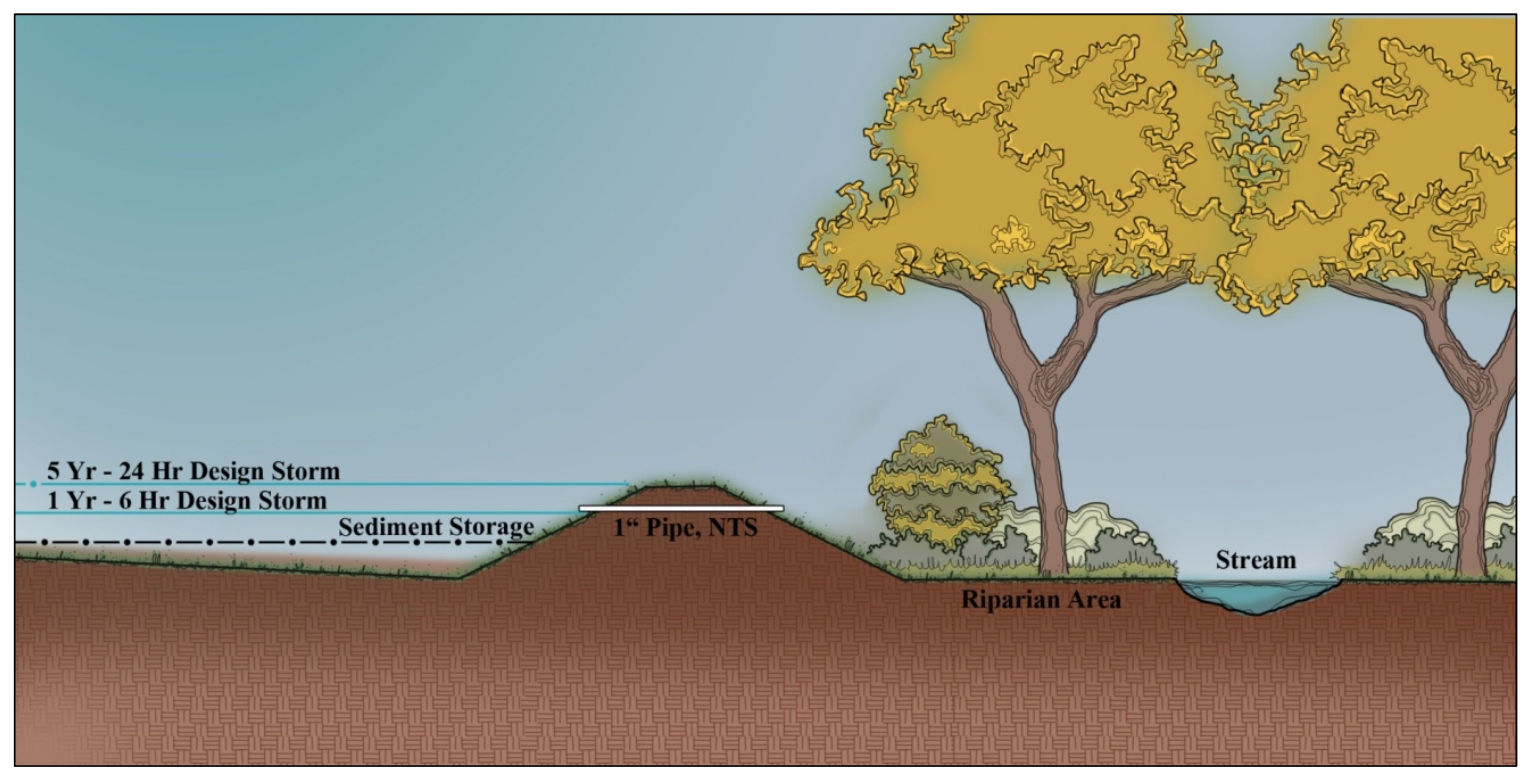

Figure 1. Cross-sectional view of a contour weep berm showing sediment storage, complete capture of frequent, small storm events, and slow release of larger storm events. Source: Warner et al. (2012). 
from a school construction site in Georgia. The contour weep berm reduced peak discharge of a 2-yr 24-h storm by $98 \%$ and suspended sediment concentrations by over $90 \%$. In a simulated rainfall study, Barnett et al. (2010) found that a contour weep berm with a VFS reduced the combined runoff volumes of all simulated storms by $96 \%$ largely through increased infiltration rates due to increased head from stored waters behind the berm (Swartzendruber and Hogarth, 1991). In a U.S. EPA-funded study evaluating the performance of silt fences and contour weep berms at a small construction site $(<1 \mathrm{ha})$ in Georgia, Sturm et al. (2007) noted that the contour weep berm completely contained all storm events throughout the entire construction timeframe. By completely containing the storm events, the contour weep berm prevented the discharge of sediment from the site during the construction phase. While the research studies testing the performance of contour weep berms are limited, the preliminary results are promising. However, for this structural BMP to undergo further refinement and testing, it is important to understand current contour weep berm design techniques. As such, this article presents the procedures for designing a contour weep berm.

\section{DESIGN METHODOLOGY \\ UPGRADIENT LAND SLOPE}

When siting a contour weep berm, consideration should be given to the slope of the land upgradient of the proposed contour weep berm location. Ideally, the upgradient land will have a slope less than 10\% (10:1 H:V); however, one of the authors has constructed contour weep berms on upgradient land slopes as steep as 25\% (4:1 H:V). Field experience by the authors indicates that upgradient land slopes steeper than $25 \%$ result in contour weep berms that treat much smaller watershed areas. For example, in a disturbed watershed requiring a $1.2 \mathrm{~m}$ tall contour weep berm to control sediment production and conservatively contain all runoff from the 5-yr 24-h storm event, a $100 \mathrm{~m}$ length of contour weep berm will treat 6.5 ha in a $2 \%$ sloped watershed versus 1 ha in a $25 \%$ sloped watershed. For steep sloped watersheds, to achieve the required sediment and runoff storage capacity needed for high levels of pollutant capture, either a series of contour weep berms and/or the excavation of upgradient soils to create trenches are needed.

\section{SOIL TYPE}

Since the purpose of the contour weep berm is to promote infiltration, careful consideration should be given to the type of soil upgradient of the contour weep berm. Sandy soils, which have high infiltration rates, will result in smaller contour weep berms with faster dewatering rates than loam or clay soils (table 1). Clay soils are not ideal for contour weep berms.

\section{DESIGN STORMS}

Contour weep berms are designed to completely contain runoff from small storm events in addition to providing
Table 1. Infiltration rates for soils.

\begin{tabular}{ccc}
\hline $\mathrm{HSG}^{[\mathrm{a}]}$ & Soil Texture & $\begin{array}{c}\text { Infiltration Rate } \\
(\mathrm{mm} / \mathrm{h})\end{array}$ \\
\hline $\mathrm{A}$ & Sand, loamy sand, sandy loam & $>7.6$ \\
$\mathrm{~B}$ & Silt loam, loam & $3.8-7.6$ \\
$\mathrm{C}$ & Sandy clay loam & $1.3-3.8$ \\
$\mathrm{D}$ & Clay loam, silty clay loam, & $<1.3$ \\
& sandy clay, silty clay, clay & \\
[a] & \\
Source: NRCS (2004).
\end{tabular}

sediment storage. This means that for small storms, the entire runoff volume is contained below the outlet inverts. The purpose of complete containment of these small events is to provide peak flow reduction, runoff volume reduction, and water quality treatment. Often times a 1-yr 6-h design storm is used when designing a contour weep berm for agricultural lands although the designer may choose a different design storm (Warner et al., 2012). Froehlich (2009) recommends treating the first inch of runoff when pollutant removal is a goal.

To establish the crest elevation of a contour weep berm, a larger design storm is used. Typically, a 5-yr 24-h design storm is used although the designer can choose larger or smaller events depending upon the risk tolerance for the project (Warner et al., 2012). The trade-off is between the volume of runoff captured and the storage capacity of the contour weep berm. Larger events will result in taller or longer contour weep berms and hence increased construction costs. Runoff from this design storm will exit the contour weep berm through the outlet structures in addition to losses primarily via infiltration with some seepage through the contour weep berm itself.

For events larger than the design storm used to establish the crest elevation, the contour weep berm will function like a broad-crested weir. Excess runoff will flow over the crest of the contour weep berm as a thin sheet. This small water depth results in low shear stress meaning the overflowing water will have minimal power to erode the contour weep berm, particularly once the vegetation is fully established.

\section{RUNOFF VOLUME}

Sizing the contour weep berm requires knowledge of excess rainfall volumes (i.e. runoff volumes), which means the designer must know runoff depths for the design storms and drainage area contributing runoff to the contour weep berm. The Natural Resource Conservation Service (NRCS) Curve Number (CN) method is a commonly used to compute runoff depths (SCS, 1986; McCuen, 2005; Froehlich, 2009; Taylor et al., 2009). To calculate runoff depth, the designer selects a $\mathrm{CN}$ based upon land uses and soil types or hydrologic soil groups (HSGs) at the project site. Table 2 contains typically $\mathrm{CN}$ values for agricultural lands that are used in contour weep berm designs. Note that lower CNs indicate larger amount of rainfall are intercepted and infiltrated into the soil while larger CNs mean more rainfall become runoff.

Following selection of the $\mathrm{CN}$, runoff depth is computed using equations 1-3 (NRCS, 2004). 
Table 2. Typical curve numbers for agricultural lands.

\begin{tabular}{|c|c|c|c|c|c|}
\hline \multirow[b]{2}{*}{ Land Use } & \multirow[b]{2}{*}{ Hydrologic Condition $^{[\mathrm{b}]}$} & \multicolumn{4}{|c|}{$\mathrm{HSG}^{[\mathrm{c}]}$} \\
\hline & & $\mathrm{A}$ & $\mathrm{B}$ & $\mathrm{C}$ & $\mathrm{D}$ \\
\hline Newly graded areas (pervious areas only, no vegetation) & & $77^{[a]}$ & 86 & 91 & 94 \\
\hline \multirow[t]{3}{*}{ Pasture or grassland - continuous forage for grazing ${ }^{[\mathrm{d}]}$} & Poor & 68 & 79 & 86 & 89 \\
\hline & Fair & 49 & 69 & 79 & 84 \\
\hline & Good & 39 & 61 & 74 & 80 \\
\hline \multirow[t]{2}{*}{ Row crops - straight rows ${ }^{[\mathrm{e}]}$} & Poor & 72 & 81 & 88 & 91 \\
\hline & Good & 67 & 78 & 85 & 89 \\
\hline
\end{tabular}

[a] Average runoff condition and $\mathrm{I}_{\mathrm{a}}=0.2 \mathrm{~S}$.

[b] Hydrologic condition refers to factors that affect infiltration and runoff such as canopy cover, vegetation density, and surface roughness.

[c] HSG = hydrologic soil group. HSG is a grouping of soils based upon their minimum infiltration rate after prolonged wetting.

[d] Poor $=<50 \%$ ground cover or heavily grazed; Fair: $50 \%-75 \%$ ground cover and not heavily grazed; Good: $>75 \%$ ground cover and lightly (occasionally) grazed.

[e] Poor = factors impair infiltration; Good=factors promote average or better infiltration.

Sources: NRCS (2004) and IDNR (2008).

$$
\begin{gathered}
Q=\frac{\left(P-I_{a}\right)^{2}}{\left(P-I_{a}\right)+S}, P>I_{a} \\
Q=0, P \leq I_{a} \\
I_{a}=\lambda S \\
S=\frac{25,400}{C N}-254
\end{gathered}
$$

The variable $\mathrm{Q}$ represents runoff depth; $\mathrm{P}$ is rainfall depth; $\mathrm{I}_{\mathrm{a}}$ is initial abstraction; $\mathrm{S}$ is storage or the maximum soil water retention parameter; and $\lambda$ is the initial abstraction coefficient. An initial abstraction coefficient of 0.2 is commonly used, although 0.05 was recommended by Hawkins et al. (2002). All units are in millimeters. Compute runoff volume by multiplying runoff depth by the drainage area contributing to the contour weep berm.

\section{CONTOUR WEEP BERM DiMENSIONS}

The length and height of the contour weep berm are the two primary dimensions for controlling runoff volume. Contour weep berm length is typically dictated by the extent of the NPS-generating activity. The contour weep berm length will be such that the runoff from NPSgenerating areas is captured. While there is no set minimum or maximum length for a contour weep berm, a trade-off does exist between contour weep berm length and height. Longer contour weep berms are typically shorter in height while shorter contour weep berms are normally taller. If desired, multiple contour weep berms can be used to decrease berm height by spreading the runoff volume across multiple structures.

\section{OUTLETS}

Outlets help control the rate at which the contour weep berm dewaters runoff generated from the larger design storm (e.g., 5-yr 24-h). Large outlets encourage more rapid dewatering while small outlets promote slower dewatering. The balance is between accommodating runoff from subsequent storm events and maximizing infiltration and pollutant removal via the down-gradient VFS or forested riparian buffer. Ideally, the contour weep berm design should allow for $60 \%$ dewatering within $24 \mathrm{~h}$, to accommodate potentially daily convective storms, and complete dewatering within $72 \mathrm{~h}$ for potentially larger frontal storm events.

Typically, outlets consist of a single row of evenlyspaced schedule 40 PVC pipes. The designer must determine pipe spacing and diameter by modeling the dewatering time although typical agricultural applications use $25 \mathrm{~mm}$ PVC pipes spaced at 10 to $15 \mathrm{~m}$ intervals. More advanced designs incorporate two horizontal rows of pipes at different elevations. This configuration allows for more rapid dewatering of stormwaters that are higher in the water column meaning sediment concentrations are less than waters at lower elevations.

To improve water quality treatment, it may be desirable to further spread out the flow exiting the outlet pipes across the VFS or riparian buffer (Dosskey et al., 2002; Baker et al., 2006). One common technique for distributing flow evenly is the use of level spreaders (NRCS, 1999; Winston et al., 2010). Currently, the authors are studying the effectiveness of a slotted corrugated pipe, to which the multiple outlet pipes connect, for further distributing flows across the riparian area.

\section{DOWN-GRAdiENT Vegetated FILTER STRIP/FORESTED RiPARIAN BUfFER}

As previously noted, VFS or forested riparian buffers are important components of the contour weep berm. These down-gradient areas are secondary treatment systems that help improve water quality by further promoting sedimentation, filtration and infiltration. Sabbagh et al. (2010) noted that VFS performance is closely tied to "the hydrologic and sedimentological conditions experienced by the VFS." As such, the authors recommend the use of VFSMOD (Vegetative Filter Strip Modeling System) to determine the appropriate VFS length instead of selecting a length based solely on parameters such as upgradient land slope, and vegetation characteristics (e.g., type, height, density).

\section{CONSTRUCTION AND MAINTENANCE}

In addition to design, construction and maintenance are important components of implementing a contour weep berm. Contour weep berm construction can be accomplished using typical farm equipment such as a skid steer, backhoe or track hoe. Warner et al. (2012) contains information on contour weep berm construction techniques. With regards to maintenance, little is required outside of 
periodic inspections, sediment removal, and mowing if desired. Clogging of the outlets has not been found in field trials, so far. However, it is anticipated that smaller sized outlets $(<25 \mathrm{~mm})$ may be more prone to clogging than larger ones.

\section{Costs}

The cost to construct a contour weep berm depends on the dimensions, as well as the equipment available and the experience of the operator. The $1.2 \mathrm{~m}$ tall contour weep berm examined by Warner and Collins-Camargo (2001) had an overly wide top width as the weep berm also served a dual purpose as a walking path for the Georgia school. The cost to construct this berm using a class 200 excavator was about $\$ 46$ per linear meter. Sturm et al. (2007) constructed a $0.8 \mathrm{~m}$ tall contour weep berm at a construction site in Georgia using a D6 dozer and a skid loader. The cost was about $\$ 37$ per linear meter. Contour weep berms constructed using a class 300 excavator at a surface mining operation in eastern Kentucky cost about $\$ 40$ per linear meter. The contour weep berms constructed by Guffey (2012) at a horse muck composting facility in central Kentucky cost about $\$ 37$ per linear meter to construct. One contour weep berm included a woodchip trench immediately upgradient of the berm. This woodchip trench was installed with the goal of increasing nitrogen removal rates. Based on these four studies, the expected cost to construct a contour weep berm is $\$ 37$ to $\$ 46$ per linear meter. Not included with the construction costs are maintenance costs, which will vary depending on the level of sediment generated at the site (i.e., frequency of sediment clean out) and the level of mowing desired.

\section{DESIGN EXAMPLE}

An example is provided for a contour weep berm used to manage runoff from a 1.7 ha horse muck compositing facility located in Lexington, Kentucky (Fayette County). The horse composting facility was constructed on a pasture; no liner or pad was used. According to the NRCS Web Soil Survey (WSS), soils at the site are Donerail, which is a HSG C (NRCS, 2004). The pasture is in good condition with more than $75 \%$ ground cover and no grazing. The linear extent of the down-gradient end of the horse composting facility is $150 \mathrm{~m}$, and the slope of the land upgradient of the contour weep berm is $2 \%$. Side slopes of $3: 1(\mathrm{H}: \mathrm{V})$ for the contour weep are used

This contour weep berm is to be designed to completely contain the 1-yr 6-h storm event $(48.3 \mathrm{~mm})$. The crest of the contour weep berm will be established using the 5-yr 24-h storm event $(96.5 \mathrm{~mm})$ (KDNREP, 1979). It is expected that sediment production from the composting operation will be low. As such, sediment storage of $63 \mathrm{~m}^{3}$ $\mathrm{ha}^{-1}$ will be provided for in the design (NRCS, 2010). The VFS will not be designed as part of this example.

\section{STEP 1: DeVELOP A STAGE-STORAGE RELATIONSHIP}

Establishment of the stage-storage relationship for the contour weep berm is done using a spreadsheet (e.g.,
Microsoft Excel or similar) provided the upgradient land has a fairly uniform slope; otherwise the designer can use ArcGIS or a similar software program. For ArcGIS, start by identifying the lowest point upgradient of the contour weep berm, and then for each $3 \mathrm{~cm}$ increase in elevation, determine the associated volume stored by the contour weep berm from the lowest point to a point above the expected crest height.

If using a spreadsheet, assume that the stored water and sediment will form a wedge behind the contour weep berm, as seen in figure 3. Compute the storage volume behind the $150 \mathrm{~m}$ long contour weep berm for incremental heights (e.g., $3 \mathrm{~cm}$ increments). Figure 4 contains the stage-volume relationship for the contour weep berm based on upgradient land slope.

\section{STEP 2: COMPUTE THE SEDIMENT STORAGE REQUIREMENTS}

Sediment storage requirements will vary depending on the upgradient land activities. Activities that result in land clearing or bare soil such as winter feeding of cattle are expected to generate higher sediment loads than activities that do not. When designing sediment basins, the NRCS (2010) recommends the designer allow $63 \mathrm{~m}^{3} \mathrm{ha}^{-1}$ for sediment storage. The state of Georgia requires $127 \mathrm{~m}^{3}$ of sediment storage per hectare of disturbed land (Georgia Soil and Water Conservation Commission, 2000). To maintain sediment storage capacity over time, periodic removal of accumulated sediment is needed.

Since the horse muck composting facility does not involve the clearing of land, the lower sediment storage

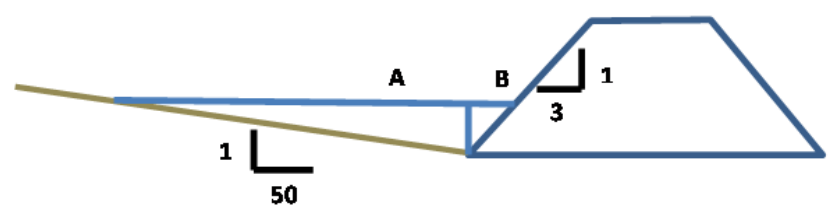

Figure 3. Water and sediment form a wedge behind the weep berm. The stage-storage relationship is determined by computing and summing the areas of triangles $A$ and $B$ for each depth increment. Not to scale.

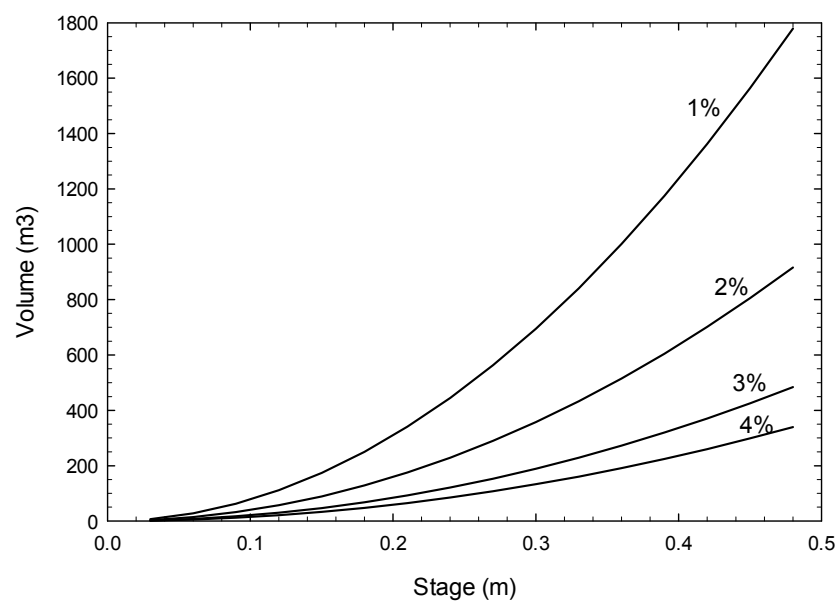

Figure 4. Stage-volume relationships for various upgradient land slopes. 
volume of $63 \mathrm{~m}^{3} \mathrm{ha}^{-1}$ is used. For $1.7 \mathrm{ha}, 107 \mathrm{~m}^{3}$ of sediment storage is required. From the stage-storage relationship, it was determined that a stage of $0.16 \mathrm{~m}$ is needed to accommodate a storage volume of $107 \mathrm{~m}^{3}$.

\section{STEP 3: COMPUTE THE RUNOFF VOLUME FOR THE 1-YR 6-H DESIGN STORM}

Using table 2, the $\mathrm{CN}$ for a Donerail (HSG C) in good condition is 74. The 1-yr 6-h rainfall depth for Lexington, Kentucky, is $48.3 \mathrm{~mm}$. Using equations $1-3$ and a $\lambda$ of 0.2 , the runoff volume for the 1.7 ha composting facility is determined to be $132 \mathrm{~m}^{3}$.

\section{STEP 4: DETERMine THE OUTLET INVERT ELEVATION}

For this design, a single outlet level was chosen although multiple levels can be used. The elevation of the outlet inverts is determined by adding the volume required for sediment storage $\left(107 \mathrm{~m}^{3}\right)$ and the runoff volume from the 1-yr 6-h design storm $\left(132 \mathrm{~m}^{3}\right)$. Thus, a stage of $0.24 \mathrm{~m}$ is needed based on the combined sediment and runoff volume of $239 \mathrm{~m}^{3}$. This stage corresponds to the lowest point of elevation along the contour weep berm.

\section{STEP 5: COMPUTE THE RUNOFF VOLUME FOR THE 5-YR 24-H DESIGN STORM}

Follow the procedure in Step 3 except use a rainfall depth of $96.5 \mathrm{~mm}$. The runoff volume for the 5-yr 24-h storm and 1.7 ha composting facility is $626 \mathrm{~m}^{3}$.

\section{Step 6: Determine The CRest Elevation}

The crest elevation is determined by adding the required sediment storage volume and the runoff volume for the 5-yr 24-h design storm. Thus, a stage of $0.40 \mathrm{~m}$ is needed. As with the outlet invert elevation, the stage of the crest elevation is based on the lowest point of elevation along the contour weep berm. Seeding and the placement of erosion control blanket along the crest of the contour weep berm helps to prevent erosion of the crest in the event of overtopping. If desired, check the shear velocity produced along the crest during larger storm events (e.g., 10-yr 24-h).

\section{STEP 7: OUTLET TYPE AND SizE}

The diameter and spacing of outlet pipes will control the rate of discharge through the contour weep berm, for the portion of the stored volume above the outlet invert elevation. To maximize the effectiveness of the downgradient VFS or forested riparian buffer, stored water should be discharged uniformly. Figure 5 contains the relationship between water level above the pipe invert and the amount of water discharged through a single pipe with a diameter of 25 or $51 \mathrm{~mm}$. These relationships were developed using HY-8, which is a culvert hydraulic analysis program developed by the United States Department of Transportation, Federal Highway Administration (FHWA, 2013). This figure assumes that none of the stored water infiltrates, and as such, will result in a conservative design.

The number of pipes needed is determined through trial and error. The designer compares the number of pipes to install in the contour weep berm to the time required to

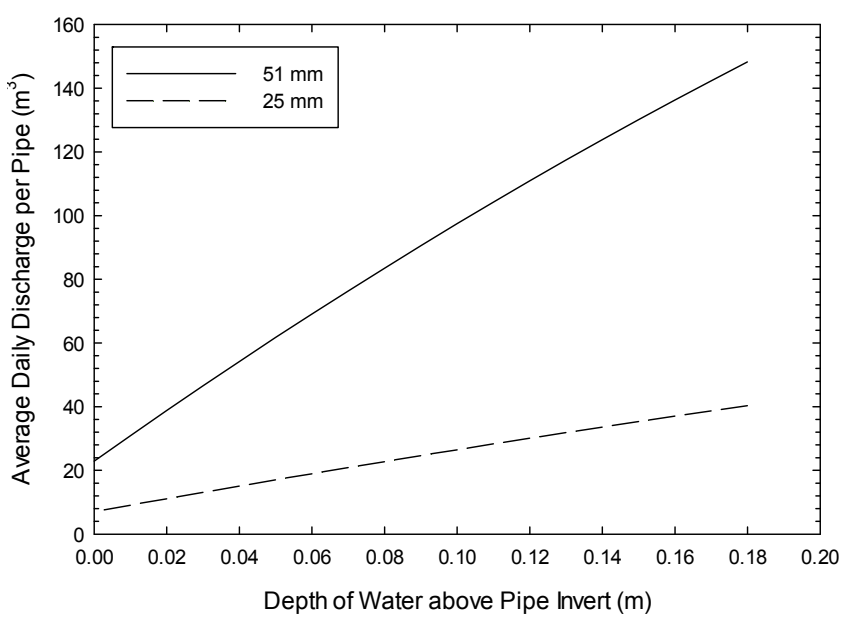

Figure 5. Average daily discharge for a single pipe based on depth of water above the pipe invert.

discharge $60 \%$ and $100 \%$ of the runoff stored above the pipe inverts. In this example, a $25 \mathrm{~mm}$ pipe diameter is selected. To dewater $60 \%$ of the stored water within $24 \mathrm{~h}$ and $100 \%$ within 72 h, 10 pipes are needed.

In this example, for the maximum water depth considered was $0.18 \mathrm{~m}$ above the pipe invert, the velocity of the water exiting the pipes is about $0.9 \mathrm{~m} \mathrm{~s}^{-1}$. For a good stand of Kentucky bluegrass (retardance class C) on a silt loam soil with a slope of $2 \%$, the maximum permissible velocity is $1.5 \mathrm{~m} \mathrm{~s}^{-1}$ (Temple, 1980). To reduce the impact velocity of the water exiting the pipes, placement of rock (e.g., No. 2 size) down gradient of the pipes is recommended.

\section{CONCLUSIONS}

A contour weep berm is an earthen berm constructed down-gradient of NPS producing activities such as land clearing at construction sites, composting facilities, or even surface mining operations. The contour weep berm is designed to control runoff volume and rates by slowing flows and promoting infiltration and sedimentation in an effort to improve water quality. Contour weep berms are used in conjunction with a VFS or forested riparian buffer as part of a treatment train. The weep berm provides the primary treatment while the VFS or forested riparian buffer provides secondary treatment. Research by Warner and Collins-Camargo (2001) and Sturm et al. (2007) indicates that contour weep berms are effective at controlling sediment-laden runoff at small construction sites, but little is known about how these systems will function in an agricultural setting.

Efforts are presently underway to further evaluate the performance of contour weep berms at two agricultural operations in central Kentucky (Atkinson, 2010; Guffey, 2012). Preliminary results from one of the study sites indicate that the contour weep berms installed there have, so far, prevented all runoff from the composting facility from entering a stream. During the one-year monitoring period, the site experienced a rainfall depth of $49 \mathrm{~mm}$ in about $9 \mathrm{~h}$ which is equivalent to the 1-yr 6-h design storm 
depth. As designed, this storm event was completed contained behind the contour weep berm. Runoff containment of such storm events reduces storm volumes and peak discharges and promotes constituent removal through sedimentation as well as adsorption and biological degradation as the runoff infiltrates into the soil. Continued monitoring of contour weep berm systems is needed to better assess their performance as an agricultural BMP.

\section{ACKNOWLEDGEMENTS}

The authors would like to thank Corey Wilson of the University of Kentucky for her assistance in developing the figures. The authors would also like to thank Dr. Terry Sturm of Georgia Tech University for his assistance in develop the stage-discharge curves for the outlet structures. This project was funded by the U.S. Department of Agriculture, Natural Resource Conservation Service (685C16-10-058). Any opinions, findings, and conclusions or recommendations expressed in this publication are those of the authors and do not necessarily reflect the views of the United States Department of Agriculture, Natural Resource Conservation Service.

\section{REFERENCES}

Agouridis, C. T., S. R. Workman, R. C. Warner, and G. D. Jennings. 2005. Livestock grazing management impacts on stream water quality: A review. JAWRA 41(3): 591-606.

Atkinson, T. 2010. Hydrologic and water quality performance of a weep berm-grass filter system for runoff from stockpiled horse muck: a preliminary study. M.S. thesis. Lexington, Ky.: University of Kentucky.

Baker, J. L., M. Helmers, and J. M. Laflen. 2006. Water management practices: Rain-fed cropland. In Environmental Benefits of Conservation on Cropland: The Status of Our Knowledge, eds. M. Schnepf and C. Cox. Ankeny, Iowa: Soil and Water Conservation Society.

Barnett, J. R., R. C. Warner, C. T. Agouridis, and D. R. Edwards. 2010. Ability of a weep berm to enhance grass filter performance in a simulated grazed system: Preliminary results. Nat. Environ. Sci. 1(1): 12-20.

Castelle, A. J., A. W. Johnson, and C. Conolly. 1994. Wetland and stream buffer size requirements: A review. J. Environ. Qual. 23(5): 878-882.

Daniels, R. B., and J. W. Gilliam. 1996. Sediment and chemical load reduction by grass and riparian filters. SSSAJ 60(1): 246251.

Deletic, A., and T. D. Fletcher. 2006. Performance of grass filters used for stormwater treatment - A field and modelling study. $J$. Hydrol. 317(3-4): 261-275.

Diaz, R. J., and R. Rosenberg. 2008. Spreading dead zones and consequences for marine ecosystems. Science 321: 926-929.

Dillaha, T. A., J. H. Sherrard, D. Lee, S. Mostaghimi, and V. O. Shanholtz. 1988. Evaluation of vegetative strips as a best management practice for feed lots. J. Water Pollut. Control Fed. 60(7): 1231-1238.

Dillaha, T. A., R. B. Reneau, and S. Mostaghimi. 1989. Vegetative filter strips for agricultural nonpoint source pollution control. Trans. ASAE 32(2): 513-519.

Dosskey, M. G., M. J. Helmers, D. E. Eisenhauer, T. G. Franti, and K. D. Hoagland. 2002. Assessment of concentrated flow through riparian buffers. J. Soil. and Water Conserv. 57(6): 336-343.
Edge, T. A., E. El-Shaarawi, V. Gannon, C. Jokinen, R. Kent, I. U. H. Khan, W. Koning, D. Lapen, J. Miller, N. Neumann, R. Phillips, W. Robertson, H. Schreier, A. Scott, I. Shtepani, E. Topp, G. Wilkes, and E. van Bochove. 2012. Investigation of an Escherichia coli environmental benchmark for waterborne pathogens in agricultural watersheds in Canada. J. Environ. Qual. 41(1): 21-30.

Federal Highway Administration (FHWA). 2013. HY-8 Version 7.3 Quick Start Guide. U.S. Department of Transportation. Available at: http://www.fhwa.dot.gov/engineering/hydraulics/software/ hy8/quick73.pdf. Accessed 14 March 2013.

Federal Interagency Stream Restoration Working Group (FISRWG). 1998. Stream Corridor Restoration: Principles, Processes, and Practices. Federal Interagency Stream Restoration Working Group, GPO Item No. 0120-A, SuDocs No. A 57.6/2:EN3/ PT.653, Washington, D.C.

Froehlich, D. C. 2009. Graphical calculation of first-flush flow rates for storm-water quality control. J. Irrig. Drain E-ASCE 135(1): $68-75$.

Georgia Soil and Water Conservation Commission. 2000. Manual for Erosion and Sediment Control in Georgia. $5^{\text {th }}$ ed. Georgia Soil and Water Conservation Commission. Available at: http://www.gaepd.org/Documents/esc_manual.html. Accessed 10 April 2012.

Guffey, R. 2012. Evaluating the effectiveness of weep berm systems for treating runoff from a horse muck composting operation. M.S. thesis. Lexington, Ky.: University of Kentucky.

Gumiere, S. J., Y. L. Bissonnais, D. Raclot, and B. Cheviron. 2011. Vegetated filter effects on sedimentological connectivity of agricultural catchments in erosion modeling: a review. Earth Surf. Proc. Land. 36(1): 3-19.

Hawkins, R. H., D. E. Woodward, and R. Jiang. 2002. Investigation of the runoff curve number abstraction ratio. USDA-NRCS Hydraulic Engineering Workshop, Las Vegas, N.V.

Iowa Department of Natural Resources (IDNR). 2008. 2C-5 NRCS TR-555 Methodology. In Iowa Stormwater Management Manual. Available at: http:/www.iowadnr.gov/Portals/idnr/ uploads/water/stormwater/manual/stormwatermanual.pdf. Accessed 14 March 2013.

Kentucky Department of Natural Resources and Environmental Protection (KDNREP). 1979. Rainfall frequency values for Kentucky. Engineering Memorandum No. 2 (4-30-71), Revised (6-1-79). Available at: http://water.ky.gov/permitting/ Documents/WRRainfall_Frequency.pdf. Accessed 22 January 2009.

Logan, T. J. 1990. Agricultural best management practices and groundwater protection. J. Soil. and Water Conserv. 45(2): 201206.

Madison, C. E., R. L. Blevins, W. W. Frye, and B. J. Barfield. 1992. Tillage and grass filter strip effects upon sediment and chemical losses. In Agronomy Abstracts. Madison, Wis.: ASA.

Magette, W. L., R. B. Brinsfield, R. E. Palmer, and J. D. Wood. 1989. Nutrient and sediment removal by vegetated filter strips. Trans. ASAE 32(2): 663-667.

McCuen, R. H. 2005. Hydrologic Analysis and Design, $3^{\text {rd }}$ ed. Upper Saddle River, N.J.: Pearson-Prentice Hall.

McFarland, M. J., A. M. S. McFarland, and J. M. Sweeten. 1990. BMP programs to control NPS pollution from animal wastes. Available at: http://tammi.tamu.edu/JOE.pdf. Accessed 14 June 2009.

Natural Resource Conservation Service (NRCS). 1999. Level spreader: Code 870. Illinois urban manual practice standard. Available at: ftp://ftp-fc.sc.egov.usda.gov/IL/urbanmnl/sections/ standards/urbst870.pdf. Accessed 14 March 2013. 
Natural Resource Conservation Service (NRCS). 2004. Chapter 10: Estimation of Direct Runoff from Storm Rainfall. In National Engineering Handbook (NEH Part 630). Available at: ftp://ftp.wcc.nrcs.usda.gov/wntsc/H\&H/NEHhydrology/ch10.pd f. Accessed 10 April 2007.

Natural Resource Conservation Service (NRCS). 2010. Conservation Practice Standard No. 350, Sediment Basin. Available at: http://efotg.sc.egov.usda.gov/references/public/ MN/350mn.pdf. Accessed 1 August 2012.

Rabalais, N. N., R. E. Turner, B. K. Sen Gupta, D. F. Boesch, P. Chapman, and M. C. Murrell. 2007. Hypoxia in the Northern Gulf of Mexico: Does the science support the plan to reduce, mitigate, and control hypoxia? Estuar. Coast. 30(5): 753-772.

Roberts, W. M., M. I. Stutter, and P. M. Haygarth. 2012. Phosphorus retention and remobilization in vegetated buffer strips: a review. J. Environ. Qual. 41(2): 389-399.

Rosen, B. 2000. Waterborne Pathogens in Agricultural Watersheds. Burlington, Vt.: U.S. Department of Agriculture, Natural Resources Conservation Service, Watershed Science Institute, School of Natural Resources, University of Vermont. Available at: ftp://ftp-fc.sc.egov.usda.gov/WSI/pdffiles/Pathogens_in Agricultural_Watersheds.pdf. Accessed 8 July 2011.

Sabbagh, G. J., G. A. Fox, R. Muñoz-Carpena, and M. F. Lenz. 2010. Revised framework for pesticide aquatic environmental exposure assessment that accounts for vegetated filter strips. Environ. Sci. Technol. 44(10): 3839-3845.

Soil Conservation Service (SCS). 1986. Urban Hydrology for Small Watersheds. Technical Release No. 55. Washington, D.C.: Soil Conservation Service, U.S. Department of Agriculture.

Sturm, T. W., R. Warner, S. Torrealba, and F. Hamade. 2007. Demonstration of a performance based system of storm water and erosion controls on small residential/commercial sites in the Georgia Piedmont. Final report to the U.S. Environmental Protection Agency, Region 4, Atlanta, Ga.

Sutherland, A. B., and J. L. Meyer. 2007. Effects of increased suspended sediment on growth rate and gill condition of two southern Appalachian minnows. Environ. Biol. Fish. 80(4): 389403.
Swartzendruber, D., and W. L. Hogarth. 1991. Water infiltration into soil in response to ponded-water head. SSSAJ 55(6): 1511-1515.

Taylor, T. J., C. T. Agouridis, R. C. Warner, and C. D. Barton. 2009. Runoff curve numbers for loose-dumped spoil in the Cumberland Plateau of eastern Kentucky. Int. J. Mini. Reclamat. Environ. 23(2): 103-120.

Temple, D. 1980. Tractive force design of vegetated channels. Trans. ASAE 23(4): 884-890.

United States Environmental Protection Agency (USEPA). 2012. Watershed Assessment, Tracking and Environmental Results: National Summary of State Information. Available at: http://ofmpub.epa.gov/waters10/attains_index.control\#status_of data. Accessed 15 August 2012.

Vuori, K. M. 1995. Direct and indirect effects of iron on river ecosystems. Ann. Zool. Fennici. 32(3): 317-329.

Warner, R. C., C. T. Agouridis, and R. Guffey. 2012. AEN-114 Using weep berms to improve water quality. Lexington, Ky.: University of Kentucky Cooperative Extension. Available at: http://www.ca.uky.edu/agc/pubs/AEN/AEN114/AEN114.pdf.

Warner, R. C., and F. X. Collins Camargo. 2001. Erosion prevention and sediment control computer modeling project. Final report for the Chattahoochee-Flint Regional Development Center Dirt II Committee, Atlanta, Ga.

World Environmental Federation and the American Society of Civil Engineers (WEF and ASCE). 2012. Design of Urban Stormwater Controls. Alexandria, Va.: WEF Press.

Winston, R. J., W. F. Hunt, W. G. Lord, and A. C. Lucas. 2010. Level spreader update: Design, construction, and maintenance. North Carolina Cooperative Extension Urban Waterways Series. Available at: http://www.bae.ncsu.edu/stormwater/PublicationFiles/LevelSpre aderDesign.Update2010.pdf.

Wood, P. J., and P. D. Armitage. 1997. Biological effects of fine sediment in the lotic environment. Environ. Manage. 21(2): 203217.

Yu, C., B. Gao, and R. Muñoz-Carpena. 2012. Effect of dense vegetation on colloid transport and removal in surface runoff. $J$. Hydrol. 434-435(1): 1-6. 